Major Powell explained that the L.S. Survey system is very economical when the colour patterns are transferred to stones.

Prof. T. McK. Hughes thought it very difficult to devise a scheme that will meet the demands of everyone. Some reference must be had to the permanence of the colours, the readiness with which they can be applied, and the distinctness with which they show what is desired. He thinks the fittest scheme must survive.

In the afternoon, brief lectures were given by Prof. Chamberlin, Mr. Gilbert, Major Powell, and Mr. Emmons upon the geology of the country to be traversed by the long excursion.

Sixth DAY.-A Committee on International Bibliography was appointed.

The Secretary announced that Messrs. Golier and Schmidt convey an invitation from the Swiss Government to hold the sixth International Congress, in 1894, in Switzerland. Mr. Golier delivered an address in which he presented the invitation, and the Congress unanimously accepted it. The following Swiss members were appointed a local committee, with power to add to their number and to appoint the time and place of meeting: viz. Messrs. Heim, Renevier, Lang, Balzer, Schmidt, and Golier. On the motion of Prof. Pumpelly, a vote of thanks was passed to the Swiss Government and delegation. It is thought that Berne will be selected as the place of meeting.

The Geological Survey of Russia sent an invitation to hold the seventh Congress in Russia. The Czar joined in the invitation. Prof. Tschernychew made the formal presentation of the subject to the Congress. A vote of thanks to the Survey and the Czar was passed, and the Secretary of the Congress was authorized to send a despatch by cable, transmitting the vote.

The President of the Congress, Prof. Le Conte, delivered a bricf closing address, summarizing the work of the session, and after passing several votes of thanks the Congress adjourned.

\section{THE SOCIETY OF FRIENDS OF ASTRONOMY AND COSMIC PHYSICS.}

THE Society of Friends of Astronomy and Cosmic Physics, founded May 19, I89I, has been formed with a view to the organization of systematic activity and co-operation in research in the subjects named. It is intended to embrace, chiefly, workers in astronomical science in Germany, Austro-Hungary, Switzerland, and other neighbouring countries, and natives of these countries in the colonies and elsewhere. Members of other nationalities are, however, offered a welcome.

The head centre of the Society is Berlin. The subscription is 5 marks.

Communications are invited from individual members, which will be published together with the notices of meetings and other business of the Society. These publications will bear the title "Mittheilungen der Vereinigung von Freunden der Astronomie und kosmischen Physik"; they will be numbered consecutively, and will be supplied to all members gratis, but will not be issued at regular or stated intervals.

These communications will form at present the only direct publication of the Society, until it is formed on a more substantial financial basis and consists of a larger number of members (in the first four weeks the number rose from 50 to over roo). Contemporaries are at liberty to borrow any matters of interest contained in the Society's communications, of course acknowledging the source from which they are derived.

Endeavours will be made to keep the Society carefully within the limits in which alone it can be successfully active, leaving on one side other closely related branches : for instance, those of the Meteorological and Photographic Societies; but, nevertheless, endeavouring to preserve the closest amity and co-operation with the related Societies.

The Astronomische Gesellschaft, founded in Germany in 1863 , is regarded by the new Society as the principal Society, whose office it is to foster astronomical research throughout the whole earth. The new Society bears the same relation to this international association as do those Astronomical Societies already established in England, France, Russia, and North America.

The principal object of these smaller societies is to collect observations made in the largest possible number of districts, inasmuch as researches in astronomy and cosmic physics are very largely dependent on the state of the weather, and the relation of the place of observation to the phenomena in the heavens.

$$
\text { NO. I [ } 43 \text {, VOL. } 44]
$$

In the new Society the following branches of work have been selected:-(1) Observations of the sun; (2) of the moon and surface of the planets; (3) of the intensity and colour of the light of the stars and of the Milky Way ; (4) of the zodiacal light and meteors ; (5) of the polar light, magnetism of the earth, earth currents, and air electricity; (6) of the clouds and halos, and thunder and lightning (care being taken in the two last groups not to encroach upon the ground already covered by the Meteorological and Photographic Societies).

Each of these groups is presided over by a member of the Society whose attention is especially directed to the respective subject. The duty of these Presidents is to organize the correspondence, hold branch meetings, and preserve the connection which binds each group to all the others.

The Society will endeavour to further the organization of all these researches, not merely by the publication of communications and by correspondence, but also by advice and aid in the providing of apparatus, especially of suitable optic, electric, and magnetic measuring instruments, charts, books, \&c.

The statutes of the Society will be sent post free on application to the Secretary, Herrn Cand. G. Witt, Berlin, N.W. Invalidenstrasse 57 .

The President of the Society is at present Prof. Dr. R. Lehmann-Filhés, Berlin, W., Wichmannstrasse I I $a$.

The Committee consists of the six members presiding over the several groups of research.

The Librarian of the Society is Herr Dr. P. Schwahn, Berlin, N.W., Invalidenstrasse 57 ; and the Treasurer; 10 whom subscriptions should be sent, Herr Rendant Bruck, Berlin, N.W., Invalidenstrasse 57 .

\section{THE PROTECTIVE DEVICE OF AN $A N N E L I D$.}

A MONGST a gathering of small Serpulids, \&c., received from Mr. Sinel, of Jersey, I find some interesting little worms related to the Sabellidx. They build a thin membranelike tube, about one-seventieth of an inch in diameter, coated externally with flat translucent particles of sand. Its lower end is closed, and embedded in sponge or other growths, but the upper end is free, and, when the head of the inmate is protruded, stands about a quarter of an inch high in the water. On this head are two branchial tufts, each having five branches beset with a double row of long ciliated filaments. When all are fully expanded they curve backwards, and cover an area of about one-tenth of an inch in diameter. The branches decrease in size from the inner to the outer pairs, and at the back of the longest but one in each tuft, near its base, is a chocolate or

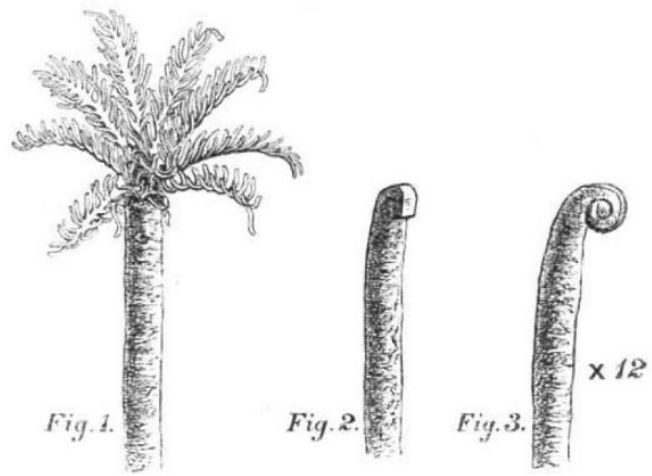

brown coloured vesicle. The two smallest branches curve backwards round the mouth of the tube, and keep up a constant whipping or flicking motion.

But the peculiarity is, that, upon the retreat of the animal, the mouth of the tube not only instantly closes flatly and tightly by collapse of the sides, but the tube itself, beginning at the tip, proceeds to coil up like a spiral spring, looking very much like a young fern-frond. This is, of course, an effectual protection against the intrusion of enemies, and the coiling and uncoiling, which I have witnessed many times, is a most curious sight.

Fig. I shows the branchial tufts expanded. Fig. 2 , tube beginning to coil up. Fig. 3, tube partly coiled up-a process which is 